Eur J Clin Chem Clin Biochem

$1995 ; 33: 351-363$

(c) 1995 Walter de Gruyter \& Co.

Berlin - New York

\title{
Exclusion of Acute Myocardial Infarction The Value of Measuring Creatine Kinase Slope
}

By Andries J. Bakker ${ }^{1}$, Mark J. W. Koelemay ${ }^{5}$, Bob van Vlies ${ }^{4}$, Jozef P. M. C. Gorgels ${ }^{3}$, Rina Smits ${ }^{1}$, Jan G. P. Tijssen ${ }^{4}$ and Frans D. M. Haagen ${ }^{2}$

1 Department of Clinical Chemistry, Stichting Klinisch Chemisch Laboratorium, Leeuwarden, The Netherlands

2 Department of Cardiology, Medisch Centrum Leeuwarden, Leeuwarden, The Netherlands

3 Department of Clinical Chemistry, Academisch Medisch Centrum, Amsterdam, The Netherlands

${ }^{4}$ Department of Cardiology, Academisch Medisch Centrum, Amsterdam, The Netherlands

5 Department of Clinical Epidemiology and Biostatistics, Academisch Medisch Centrum, Amsterdam, The Netherlands

(Received March 10, 1994/January 2, 1995)

Summary: For the exclusion (and diagnosis) of acute myocardial infarction, we studied timed sequential (slope) measurements of creatine kinase and creatine kinase-MB catalytic activity concentration, creatine kinase-MB mass concentration, troponin $\mathrm{T}$ and myoglobin, using data from 242 patients consecutively admitted for evaluation of suspected acute myocardial infarction in the 12 hours before admission. Three biochemical strategies based on measurements in two consecutive samples obtained within 12 hours after admission were evaluated. The highest sensitivities were encountered for a biochemical strategy based on the sole measurement of creatine kinase mass concentration (98\%) or troponin T (96\%) and a strategy based on measurements of creatine kinase activity concentrations, which includes creatine kinase slope calculation and measurement of creatine kinase mass concentration (95\%). Both strategies were applied in subgroups of patients based on the electrocardiographic findings. In patients with a normal electrocardiogram, the sensitivity of the strategy using sole measurements of creatine kinase mass concentration was $100 \%$, but this was also true for the strategy based on creatine kinase slope measurements, which is the cheaper and therefore preferred procedure for excluding myocardial infarction. This approach, however, does not account for detecting minor myocardial cell damage in patients not yet fulfilling the criteria of the World Health Organization for diagnosing acute myocardial infarction.

\section{Introduction}

Rapid diagnosis in patients admitted to the hospital shortly after onset of acute chest pain suggestive for myocardial ischaemia is important for clinical decision making. Appropriate treatment will be started if, based on the patient's history and initial electrocardiographic recordings, substantial evidence exists for an acute coronary event, whether unstable angina or evolving acute myocardial infarction. However, in a considerable number of patients with myocardial infarction the initial electrocardiogram is inconclusive or normal $(1,2)$.

') Enzyme: Creatine kinase, EC 2.7.3.2.
Moreover, electrocardiographic findings were reported to be variable in a substantial fraction of patients with myocardial infarction (3). Therefore, measuring the activity concentration of creatine kinase ${ }^{1}$ ) (creatine kinase; EC 2.7.3.2) and its MB-isoenzyme, which reflect myocardial cell damage, has become an important tool in establishing the definitive diagnosis of acute myocardial infarction, mainly because these enzymes can be measured rapidly with automated analyzers. Since the diagnostic value of single measurements of creatine kinase and creatine kinase-MB activity concentration is limited (4-8), serial samples need to be measured. To provide 
rapid diagnosis and exclusion of acute myocardial infarction, the measurement of creatine kinase slope values, which reduces laboratory costs, has been proposed $(9-11)$. The validity of this procedure however, has been questioned $(12,13)$.

Recently, new markers for establishing myocardial cell damage (myoglobin (14-18), creatine kinase-MB mass concentration (19-21) and troponin $\mathrm{T}(22-25))$ have become available for routine clinical practice. These new markers have a greater sensitivity for myocardial cell injury than the routinely used creatine kinase and creatine kinase-MB activity concentration and - even more important - detection is possible after a shorter time interval after onset of necrosis (26). Both features could make these new biochemical techniques highly suitable for early confirmation of myocardial infarction. However, early exclusion of myocardial infarction was shown not to be reliable unless $10-12 \mathrm{~h}$ elapsed since onset of chest pain (27). By then creatine kinase and its MB-isoenzyme, whose reagent costs are much cheaper, perform as well as the new markers.

In this study, samples from patients admitted for evaluation of suspected acute myocardial infarction were used to evaluate the effectiveness of diagnostic strategies to exclude myocardial infarction, thereby limiting laboratory costs. In the first part, we evaluated diagnostic strategies which are based on the measurement of biochemical markers only. In the second part, the performance of these diagnostic strategies was evaluated in subgroups of patients, based on the results of the electrocardiographic recordings at admission.

\section{Patients and Methods}

\section{Patients and samples}

The study population involved patients $(n=409)$ admitted during a 9-month period to the coronary care unit of the Medisch Centrum Leeuwarden hospital, a large regional hospital, for evaluation of suspected myocardial infarction in the 12 hours before admission. Patients were excluded prospectively if they had been resuscitated or defibrillated $(n=25)$, and retrospectively if the recorded time of onset of chest pain appeared not to be accurate $(n=87)$ or if as a consequence of an insufficient amount of sample $(n=55)$, not all results for the markers in both samples could be established (242 patients remained for evaluation). Standard 12-lead electrocardiograms obtained at admission, 24 hours after admission and at discharge were used to establish the definitive diagnosis. Blood samples were taken at admission, three times in a fixed time schedule (at 7.30, 14.30 and 22.30 according to the hospital sampling scheme) for the first 24 hours and once daily (at 7.30) thereafter until discharge. Sampling times were recorded as accurately as possible.

\section{Diagnostic criteria}

Classification of admission electrocardiograms

Admission electrocardiograms were classified as normal, ischaemic or inconclusive. Normal admission electrocardiograms were defined according to the criteria by the New York Heart Association (28). Admission electrocardiograms were rated ischaemic if ST segment depression $>1 \mathrm{~mm} 0.08 \mathrm{~s}$ after J point was present or ST segment elevation $>1 \mathrm{~mm}$, both in at least two contiguous leads, provided normal QRS complexes or right bundle branch block. All other admission electrocardiograms were classified as inconclusive.

\section{Final classification of the patients . .}

Patients were classified as having acute myocardial infarction, unstable angina pectoris, no acute ischaemic heart disease or other cardiac diseases. The final diagnosis was established by an independent cardiologist, without knowledge of the results of the new tests (myoglobin, creatine kinase-MB mass concentration and troponin $\mathrm{T}$ ) or the creatine kinase slope values. The diagnosis of acute myocardial infarction was made if the patient had at least two of the three classic findings:

1. Clinical history of ischaemic chest discomfort $>30$ min duration,

2. Evolution of typical changes in at least two leads of the electrocardiographic recordings. If $Q$ waves $>0.04 \mathrm{~s}$ appeared or $\mathrm{R}$ wave increment leading to an R/S ratio $>1$ in leads $V 1$ and $V 2$, it was called $Q$ wave infarction. If ST segment depression $>1 \mathrm{~mm}$ occurred $0.08 \mathrm{~s}$ after the $\mathrm{J}$ point or ST segment elevation $>1 \mathrm{~mm}$ persisted for at least $24 \mathrm{~h}$ it was called non- $\mathrm{Q}$ wave infarction.

3. Time-dependent changes of serum creatine kinase and creatine kinase-MB activity concentration with an initial rise (with a peak value for creatine kinase-MB activity concentration exceeding twice the upper reference limit) and subsequent fall.

Unstable angina pectoris was defined as typical anginal pain at rest in combination with reversible or persistent electrocardiographic changes but with a peak value of the activity concentration of creatine kinase-MB not exceeding twice the upper reference limit.

Patients were classified as having no acute ischaemic heart disease if an acute coronary event as the cause of the chest pain could be excluded.

Analytical methods

Catalytic activity concentration of creatine kinase

Creatine kinase was measured at $30^{\circ} \mathrm{C}$ with a Hitachi 717 analyzer (Boehringer Mannheim, Mannheim, Germany) by the method proposed by the International Federation of Clinical Chemistry (29) using commercial reagents (Boehringer Mannheim; prod. no. 475742 and 475769 ). The upper reference limit for this assay was $130 \mathrm{U} / 1$ for men and $90 \mathrm{U} / \mathrm{l}$ for women.

\section{Catalytic activity concentration of creatine kinase- $M B$}

Creatine kinase-MB was measured by immunoinhibition using the appropriate antibody (Boehringer Mannheim; prod. no. 418234) and the creatine kinase method. Like creatine kinase, creatine kinase-MB activity concentration was measured with the Hitachi 717 analyzer at $30^{\circ} \mathrm{C}$. The upper reference limit used for this assay was $15 \mathrm{U} / \mathrm{l}$.

\section{Mass concentration of creatine kinase-MB}

Creatine kinase-MB in serum was measured according to the manufacturer's instructions, using the microparticle capture enzyme immunoassay with the IMx analyzer (Abbott Laboratories, Abbott Park, IL; prod. no. 2207-20). The lower limit of detection for this assay was reported to be $0.2 \mu \mathrm{g} / \mathrm{l}(30)$. The measuring range covers concentrations from 0.2 to $300 \mu \mathrm{g} / 1$. The upper reference limit used for this assay was $5.0 \mu \mathrm{g}$. 


\section{Cardiac troponin $T$}

Troponin $T$ in serum was measured with an enzyme linked immunosorbent assay (Boehringer Mannheim; prod. no. 1086987) as developed by Katus et al. $(22,24)$. This assay was carried out at room temperature in coated tubes using the microprocessor controlled batch analyzer ES-33 (Boehringer Mannheim). The lower limit of detection for this assay was established at $0.10 \mu \mathrm{g} / \mathrm{l}$ (mean absorbance of zero standard + $3 \mathrm{SD}$ ), which was in concordance with Katus et al. (24). The measuring range covers concentrations from 0.1 to $15 \mu \mathrm{g} /$. The upper reference limit used for this assay was $0.1 \mu \mathrm{g} / \mathrm{l}$.

\section{Myoglobin}

Myoglobin in serum was measured with a recently described turbidimetric method (31) using commercially available reagents (Behringwerke AG, Marburg, Germany; Turbiquant myoglobin, prod. no. OWNK) adapted for use with a Hitachi 717 at $30^{\circ} \mathrm{C}$ (Boehringer Mannheim). The lower limit of detection for this assay was established at $30 \mu \mathrm{g} / \mathrm{l}$. The measuring range covers concentrations from 30 to $900 \mu \mathrm{g} / \mathrm{l}$. The upper reference limit used for this assay was $57.9 \mu \mathrm{g} / \mathrm{l}(31)$.

\section{Creatine kinase slope values}

Slope values for the individual markers were calculated after transforming the individual results logarithmically. Thereafter the change per unit of time (slope value) was established according to Collinson et al. (9). The reference value for the log creatine kinase of 0.015 per hour as reported by Collinson et al. was confirmed in the patient group without acute ischaemic heart disease (of the four patients with an elevated slope value two collapsed before admission, so muscle injury could not be excluded as a cause for this elevated slope value).

\section{Validation of reference values}

For all analytes, the reference values were primarily based on the results obtained in samples from healthy blood donors. However, according to the guidelines of the International Federation of Clinical Chemistry (32), such reference values need not be appropriate for the diseased population, so they were verified by analysis of samples obtained from patients admitted for evaluation of suspected myocardial infarction for whom a myocardial cause for the complaints was excluded at discharge from the hospital (the patients with no acute ischaemic heart disease) $(26,33)$.

\section{Statistical analysis}

Differences in baseline characteristics (age, gender, clinical history and risk factors) between patients with and without myocardial infarction were determined using a $\chi^{2}$ or Fisher's exact test for categorical and Student's $t$ test for continuous variables, respectively.

Sensitivity and specificity wère calculated to determine the diagnostic properties of the biochemical markers. Receiver-operating characteristic (ROC) curves were constructed to compare the discriminative power of the tests. Areas under the curve and differences between ROC curves were calculated as proposed by Hanley et al. $(34,35)$.

\section{Biochemical diagnostic strategies}

\section{Diagnostic strategy A}

For each individual marker, the possibility of excluding and diagnosing myocardial infarction was investigated. When the result at admission for a marker was within the reference range then, in the second sample, the same marker was determined. If both results were within the reference range, myocardial infarction was considered to be absent. Myocardial infarction was considered to be present in those cases where either the result of admission or the result in the second sample was elevated (fig. 1a). The diagnostic sensitivity and specificity of this strategy were determined for each individual marker (combining the various markers was not attempted here).

\section{Diagnostic strategy $B$}

The second diagnostic strategy was based on measurements of creatine kinase activity only (fig. 1b). When creatine kinase activity concentration was elevated in the first or the second sample, one of the other markers was measured to improve specificity. Myocardial infarction was considered to be present in those patients who had an elevated result for the second marker (myoglobin, although not cardiospecific, was included for reasons of comparison). In patients with results for creatine kinase activity concentration within the reference range at admission as well as in the second sample, acute myocardial infarction was considered to be absent and no second
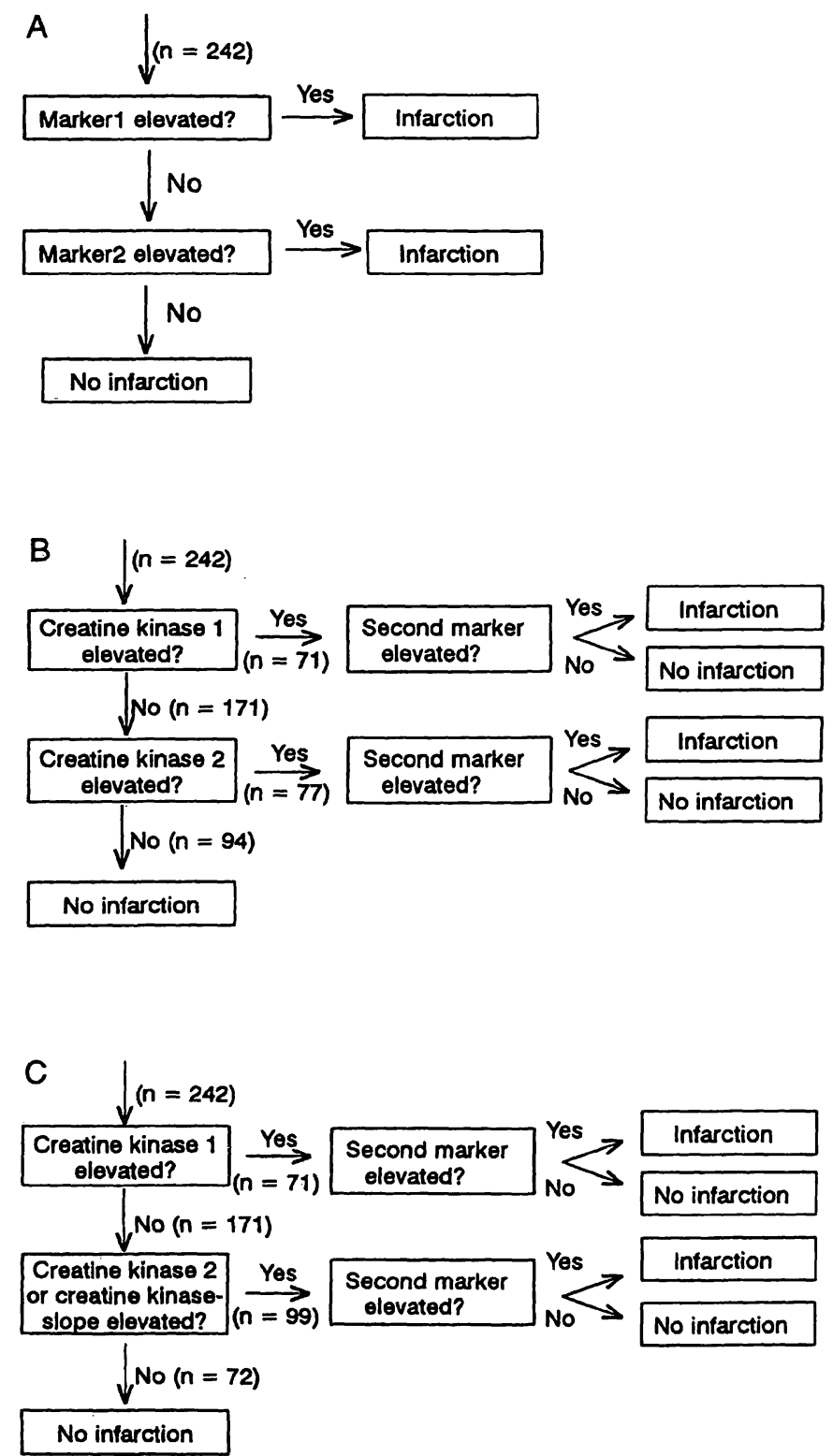

Fig. 1 Flowcharts for three biochemical diagnostic strategies for exclusion (and confirmation) of acute myocardial infarction. 
$[1 / 6 n]$ ssem gw әseu!y әи!ฺеәдว
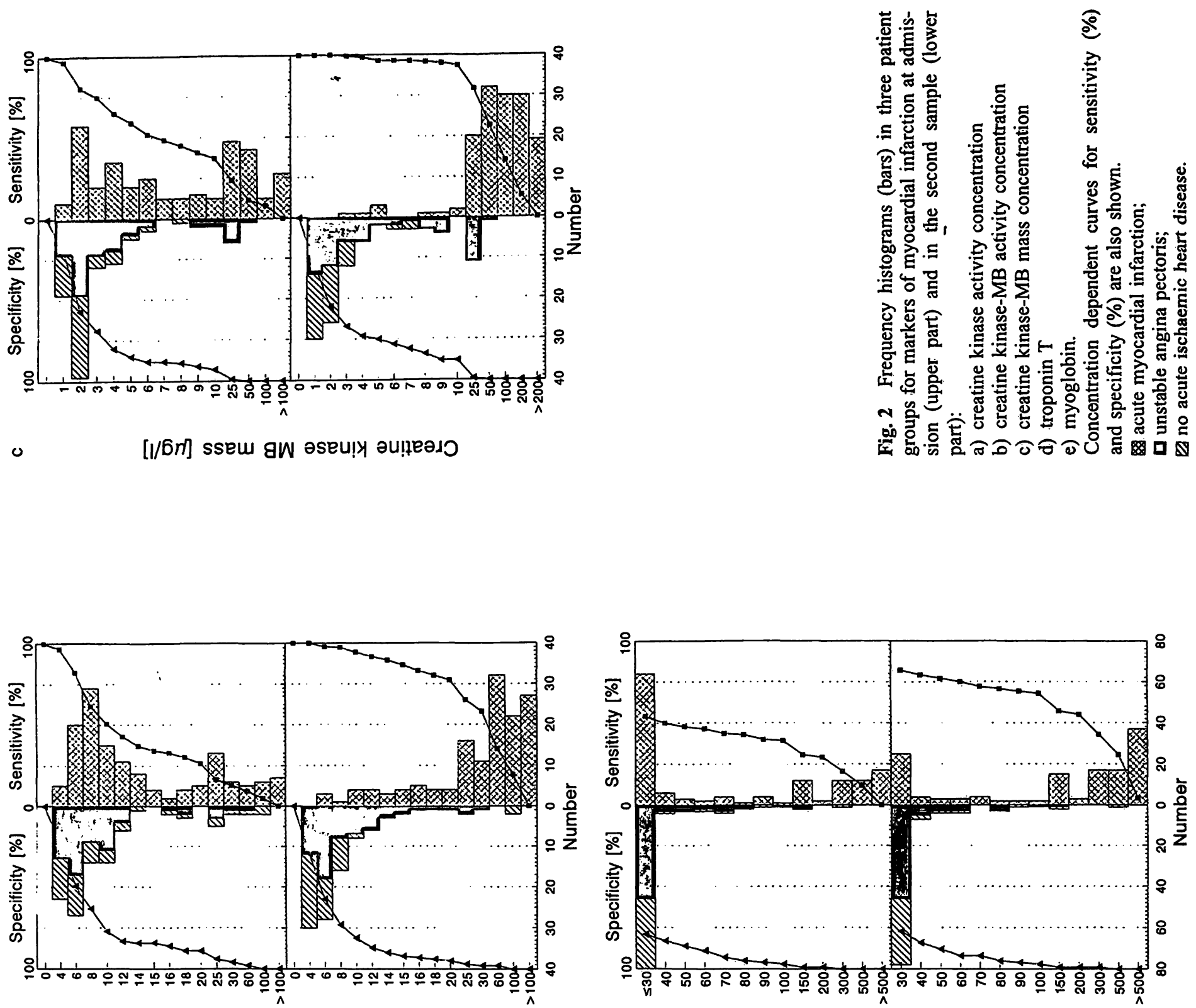

ค

$[ı / n]$ ᄉ

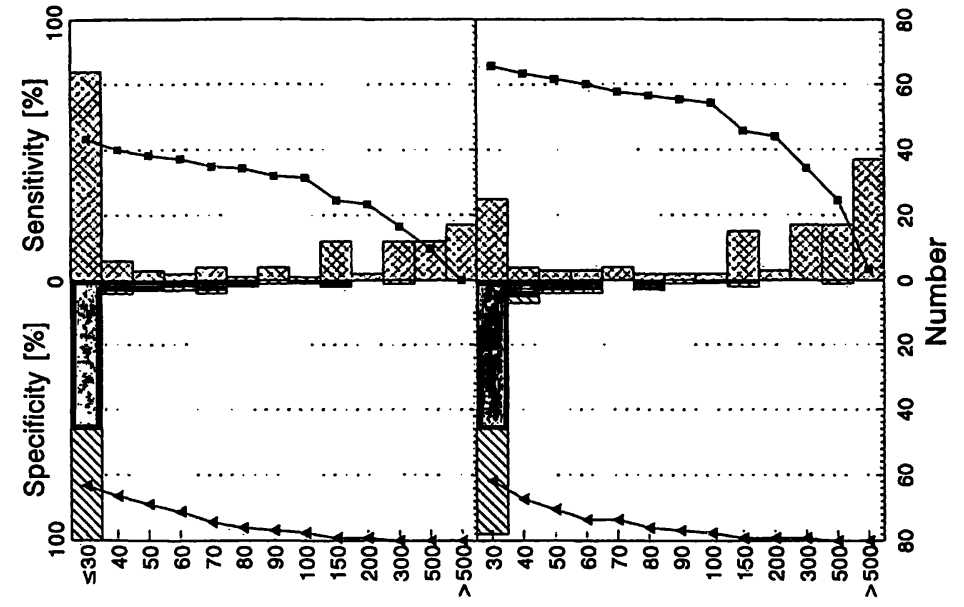

(

$[1 / 6 m]$ u!qoj6okw

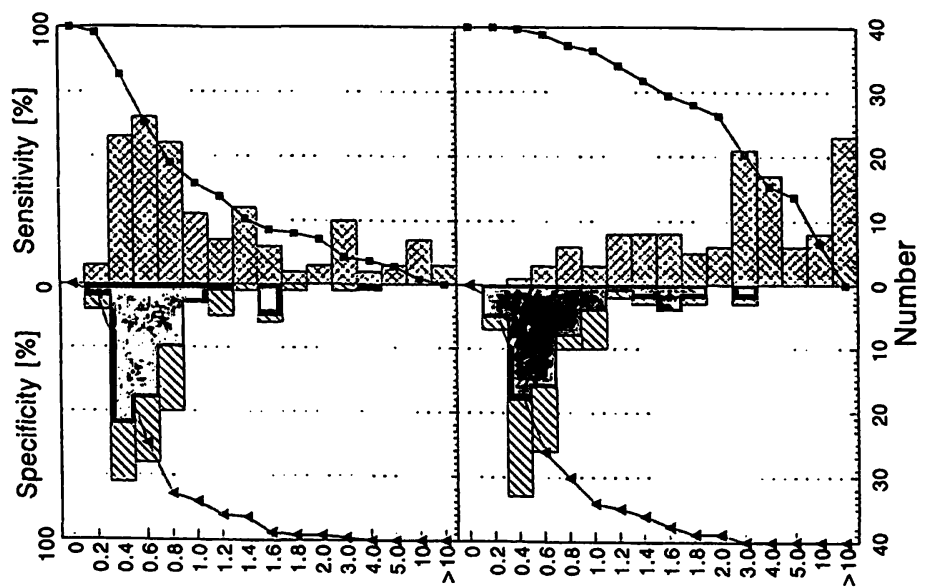

ช

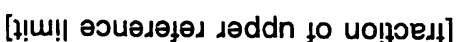

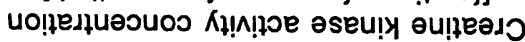

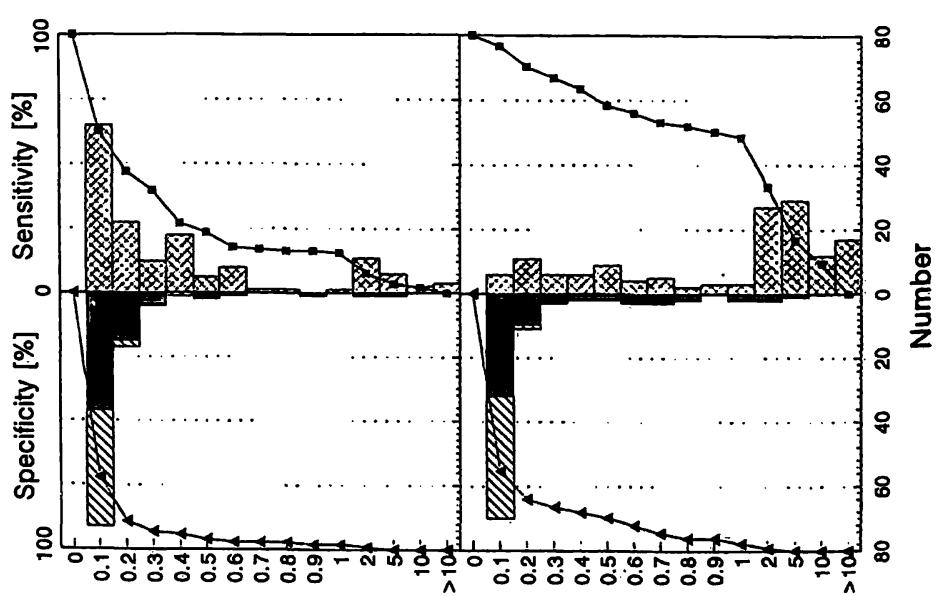

ס

$[1 / 6 r] \perp$ u!̣odoג 
marker needed to be measured. The diagnostic sensitivity and specificity were determined for the overall procedure.

\section{Diagnostic strategy $C$}

The third diagnostic strategy was almost identical to the second, but in those patients needing the measurement of creatine kinase activity concentration in the second sample, also the calculation of creatine kinase slope values was included to reduce the frequency of false-negatives (fig. 1c). When both results for creatine kinase activity concentration were within the reference range and the creatine kinase slope value was normal too, then patients were considered not to have myocardial infarction and no second marker was measured. If however, creatine kinase activity concentration in one of the samples was elevated or the creatine kinase slope value was elevated, then measurement of one of the other markers as a second marker was performed to improve specificity. Again the diagnostic sensitivity and specificity were determined for the overall procedure.

\section{Clinical strategies}

\section{Combining clinical data with biochemical strategies}

In diagnostic procedures, biochemical data are used in addition to clinical data. Therefore, the effectiveness of the biochemical strategies was evaluated in subgroups of patients. These subgroups were based on the classification of the electrocardiographic recordings at admission. Since biochemical strategy B was not as sensitive as strategy $C$, it was left out of consideration. Since the release of the various markers follows a different time-dependent pattern, the effectiveness in various time-windows was also considered.

\section{Results}

\section{Patient characteristics}

Our study encompassed 242 patients. In 141 patients acute myocardial infarction (69 Q-wave) was confirmed (43 receiving thrombolytic therapy). In 101 patients acute myocardial infarction was excluded: 51 patients were classified as having unstable angina pectoris (three received thrombolytic therapy), 39 having no acute ischaemic heart disease (one received thrombolytic therapy), in seven patients other cardiac diseases were diagnosed and in four patients no definitive diagnosis was made (one received thrombolytic therapy). No significant differences between baseline characteristics (age, gender, clinical history and risk factors) were found between patients with and without myocardial infarction.

\section{Comparing slope values with single second marker}

The first sample, taken at admission, was taken at a mean time of 4.9 hours (range: $0-12$ hours; $<3$ hours: $\mathrm{n}=93 ; 3-6$ hours: $\mathrm{n}=70 ; 6-9$ hours: $\mathrm{n}=47 ; 9-12$ hours: $n=32$ ) after the onset of chest pain. The second sample was taken at a mean time of 11.8 hours after the onset of chest pain, which is on the average 6.9 hours later than the admission sample (range $1-12$ hours; $<3$ hours: $\mathrm{n}=22 ; 3-6$ hours: $\mathrm{n}=78 ; 6-9$ hours: $\mathrm{n}=78$;
$9-12$ hours: $n=64)$. The results in the admission sample as well as the second sample for the patient groups with and without myocardial infarction are shown in figure $2 a-e$. The concentration dependent change of the sensitivity and specificity is shown in the same figure. To compare the diagnostic power of the slope value for the various markers with the diagnostic power of the individual results obtained in the first and second sample, we constructed ROC curves. The results, summarized in table 1 , indicate that single second measurements of the markers perform better than the corresponding slope values.

\section{Effect of time-delay on sensitivity and specificity}

Since the release of biochemical markers for myocardial cell damage depends on the time elapsed since onset of necrosis, the diagnostic sensitivity and specificity were calculated for more homogeneous subgroups based on the time-interval between onset of chest pain and admission and based on the time-interval between first and second sample (tab. 2). Creatine kinase-MB mass concentration and troponin $\mathrm{T}$ have considerably higher sensitivities at admission than creatine kinase and creatine kinase-MB activity concentration, although about half the patients with acute myocardial infarction still have results within the reference range for both markers when admitted within three or between three and six hours after the onset of chest pain. When more time elapses from onset, sensitivity increases considerably for. all markers except myoglobin.

\section{Effectiveness of the biochemical diagnostic strategies}

Although sensitivity for each biochemical marker increases when more time elapses after onset of chest pain, the admission sample is not sufficient for excluding (or diagnosing) acute myocardial infarction in patients admitted within 12 hours after onset of chest pain, whichever marker was used. Therefore, myocardial infarction could not be excluded unless at least a second sample was examined in patients for whom the result of a cardiac marker was within the reference range in the admission sample. In diagnostic strategy $A$ individual markers were evaluated singly. Patients with an elevated marker result in either the admission or the second sample were considered to have myocardial infarction. In the creatine kinase based diagnostic strategy $B$, patients who had an elevated result for creatine kinase in either the admission or the second sample were considered to have myocardial infarction when the measurement of a second marker also gave an elevated result. By measur- 
Tab. 1 Area under the ROC curve for the five markers measured in the first and second sample and by' slope procedure.

\begin{tabular}{llll}
\hline Marker & \multicolumn{2}{l}{ Area under the curve \pm SE) } \\
\cline { 2 - 4 } & $1^{\text {st }}$ sample & $2^{\text {nd }}$ sample & Slope \\
\hline Creatine kinase activity concentration & $0.67 \pm 0.03$ & $0.95 \pm 0.02$ & $0.91 \pm 0.02$ \\
Creatine kinase-MB activity concentration & $0.71 \pm 0.03$ & $0.95 \pm 0.01$ & $0.89 \pm 0.02$ \\
Creatine kinase-MB mass concentration & $0.79 \pm 0.03$ & $0.98 \pm 0.01$ & $0.88 \pm 0.02$ \\
Troponin T & $0.71 \pm 0.03$ & $0.93 \pm 0.02$ & $0.86 \pm 0.02$ \\
Myoglobin & $0.71 \pm 0.03$ & $0.86 \pm 0.03$ & $0.76 \pm 0.03$ \\
\hline
\end{tabular}

Tab. 2 Sensitivity and specificity for the five cardiac markers related to time since onset of chest pain ( ${ }^{\text {st }}$ sample) and time since admission ( $2^{\text {nd }}$ sample).

\begin{tabular}{|c|c|c|c|c|c|}
\hline \multirow{3}{*}{$\begin{array}{l}\text { Upper } \\
\text { reference limit }\end{array}$} & \multicolumn{5}{|l|}{ Marker } \\
\hline & $\begin{array}{l}\text { Creatine } \\
\text { kinase activity } \\
\text { concentration }\end{array}$ & $\begin{array}{l}\text { Creatine } \\
\text { kinase-MB activity } \\
\text { concentration }\end{array}$ & $\begin{array}{l}\text { Creatine } \\
\text { kinase-MB mass } \\
\text { concentration }\end{array}$ & Troponin T & Myoglobin \\
\hline & $\begin{array}{l}\delta 130 \mathrm{U} / 1 \\
q \quad 90 \mathrm{U} / 1\end{array}$ & $15 \mathrm{U} / 1$ & $5.0 \mu \mathrm{g} / 1$ & $0.1 \mu \mathrm{g} / 1$ & $57.9 \mu \mathrm{g} / 1$ \\
\hline \multicolumn{6}{|c|}{ Admission sample within 3 hours after onset } \\
\hline $\begin{array}{l}\text { Sensitivity } \\
\text { Specificity }\end{array}$ & $\begin{array}{l}24 \% \\
90 \%\end{array}$ & $\begin{array}{l}20 \% \\
79 \%\end{array}$ & $\begin{array}{l}40 \% \\
92 \%\end{array}$ & $\begin{array}{l}47 \% \\
68 \%\end{array}$ & $\begin{array}{l}29 \% \\
95 \%\end{array}$ \\
\hline \multicolumn{6}{|c|}{ Admission sample between 3 and 6 hours after onset } \\
\hline $\begin{array}{l}\text { Sensitivity } \\
\text { Specificity }\end{array}$ & $\begin{array}{l}27 \% \\
84 \%\end{array}$ & $\begin{array}{l}14 \% \\
96 \%\end{array}$ & $\begin{array}{l}56 \% \\
84 \%\end{array}$ & $\begin{array}{l}58 \% \\
88 \%\end{array}$ & $\begin{array}{l}53 \% \\
88 \%\end{array}$ \\
\hline \multicolumn{6}{|c|}{ Admission sample between 6 and 9 hours after onset } \\
\hline $\begin{array}{l}\text { Sensitivity } \\
\text { Specificity }\end{array}$ & $\begin{array}{l}64 \% \\
77 \%\end{array}$ & $\begin{array}{l}68 \% \\
91 \%\end{array}$ & $\begin{array}{l}84 \% \\
73 \%\end{array}$ & $\begin{array}{l}84 \% \\
64 \%\end{array}$ & $\begin{array}{l}64 \% \\
91 \%\end{array}$ \\
\hline \multicolumn{6}{|c|}{ Admission sample between 9 and 12 hours after onset } \\
\hline $\begin{array}{l}\text { Sensitivity } \\
\text { Specificity }\end{array}$ & $\begin{array}{l}88 \% \\
88 \%\end{array}$ & $\begin{array}{l}88 \% \\
69 \%\end{array}$ & $\begin{array}{l}94 \% \\
88 \%\end{array}$ & $\begin{array}{l}94 \% \\
69 \%\end{array}$ & $\begin{array}{l}69 \% \\
75 \%\end{array}$ \\
\hline \multicolumn{6}{|c|}{ Second sample obtained within 6 hours after the first } \\
\hline $\begin{array}{l}\text { Sensitivity } \\
\text { Specificity }\end{array}$ & $\begin{array}{l}88 \% \\
83 \%\end{array}$ & $\begin{array}{l}79 \% \\
90 \%\end{array}$ & $\begin{array}{l}95 \% \\
70 \%\end{array}$ & $\begin{array}{l}93 \% \\
63 \%\end{array}$ & $\begin{array}{l}88 \% \\
88 \%\end{array}$ \\
\hline \multicolumn{6}{|c|}{ Second sample obtained between 6 and 12 hours after the first } \\
\hline $\begin{array}{l}\text { Sensitivity } \\
\text { Specificity }\end{array}$ & $\begin{array}{l}93 \% \\
87 \%\end{array}$ & $\begin{array}{l}91 \% \\
93 \%\end{array}$ & $\begin{array}{l}98 \% \\
79 \%\end{array}$ & $\begin{array}{l}98 \% \\
74 \%\end{array}$ & $\begin{array}{l}62 \% \\
95 \%\end{array}$ \\
\hline
\end{tabular}

ing the second marker, the amount of false-positives could be reduced. In the creatine kinase based diagnostic strategy $\mathrm{C}$, the sensitivity was increased by also measuring the second marker in those second samples for which the creatine kinase slope procedure produced an elevated result. The diagnoses resulting from these biochemical strategies were compared with the final diagnoses. The sensitivity and specificity for each procedure is shown in table 3.

In the creatine kinase based diagnostic strategies $B$ and $C$, the frequency of false-positives was reduced by assaying a second marker. However, this procedure intro- duced additional false-negatives. Table 4 shows the number of false-positives and false-negatives for each individual step of both procedures. Of the 93 patients for whom myocardial infarction was considered to be absent based on strategy B, 13 patients still had a definitive diagnosis of myocardial infarction; some but not all of them could be detected by measuring one of the other markers (tab. 4). On the basis of strategy $C$, in 71 patients myocardial infarction was considered to be absent, but five out of these 71 still had a definitive diagnosis of acute myocardial infarction. Further analysis of the data from these five patients revealed that by use of samples taken after a longer time interval since 
Tab. 3 Overall sensitivity (\%) and specificity (\%) for the three biochemical diagnostic strategies (explained in the method section).

\begin{tabular}{|c|c|c|c|c|c|}
\hline & \multicolumn{5}{|l|}{ Marker } \\
\hline & $\begin{array}{l}\text { Creatine } \\
\text { kinase activity } \\
\text { concentration }\end{array}$ & $\begin{array}{l}\text { Creatine } \\
\text { kinase-MB activity } \\
\text { concentration }\end{array}$ & $\begin{array}{l}\text { Creatine } \\
\text { kinase-MB mass } \\
\text { concentration }\end{array}$ & Troponin T & Myoglobin \\
\hline \multicolumn{6}{|c|}{ Diagnostic strategy A: } \\
\hline \multirow[t]{3}{*}{$\begin{array}{l}\text { Sensitivity } \\
\text { Specificity }\end{array}$} & $\begin{array}{l}91 \\
79\end{array}$ & $\begin{array}{l}88 \\
82\end{array}$ & $\begin{array}{l}98 \\
74\end{array}$ & $\begin{array}{l}96 \\
58\end{array}$ & $\begin{array}{l}80 \\
87\end{array}$ \\
\hline & First marker & Second marker & & & \\
\hline & $\begin{array}{l}\text { Creatine } \\
\text { kinase activity } \\
\text { concentration }\end{array}$ & $\begin{array}{l}\text { Creatine } \\
\text { kinase-MB activity } \\
\text { concentration }\end{array}$ & $\begin{array}{l}\text { Creatine } \\
\text { kinase-MB mass } \\
\text { concentration }\end{array}$ & Troponin $\mathrm{T}$ & Myoglobin \\
\hline \multicolumn{6}{|c|}{ Diagnostic strategy $B$} \\
\hline $\begin{array}{l}\text { Sensitivity } \\
\text { Specificity }\end{array}$ & $\begin{array}{l}91 \\
79\end{array}$ & $\begin{array}{l}76 \\
93\end{array}$ & $\begin{array}{l}90 \\
89\end{array}$ & $\begin{array}{l}87 \\
89\end{array}$ & $\begin{array}{l}69 \\
94\end{array}$ \\
\hline \multicolumn{6}{|c|}{ Diagnostic strategy $C:$} \\
\hline $\begin{array}{l}\text { Sensitivity } \\
\text { Specificity }\end{array}$ & $\begin{array}{l}96 \\
66\end{array}$ & $\begin{array}{l}78 \\
92\end{array}$ & $\begin{array}{l}95 \\
82\end{array}$ & $\begin{array}{l}91 \\
81\end{array}$ & $\begin{array}{l}72 \\
92\end{array}$ \\
\hline
\end{tabular}

Tab. 4 Frequency of false-positive and false-negative results for the various steps of the creatine kinase based biochemical diagnostic strategies (see method section).

\begin{tabular}{|c|c|c|c|c|c|c|c|c|c|c|}
\hline & \multirow{2}{*}{\multicolumn{2}{|c|}{$\begin{array}{l}\text { First } \\
\text { CK }>\text { URL }\end{array}$}} & \multicolumn{4}{|c|}{ Diagnostic strategy B } & \multicolumn{4}{|c|}{ Diagnostic strategy $C$} \\
\hline & & & \multicolumn{2}{|c|}{$\begin{array}{l}\text { Second } \\
\text { CK }>\text { URL }\end{array}$} & \multicolumn{2}{|c|}{$\begin{array}{l}\text { Remaining } \\
\text { (CK \& URL) }\end{array}$} & \multicolumn{2}{|c|}{$\begin{array}{l}\text { Slope } \\
\text { CK }>0.015\end{array}$} & \multicolumn{2}{|c|}{$\begin{array}{l}\text { Remaining } \\
\text { (CK-slope } \leqslant 0.015\end{array}$} \\
\hline \multirow[t]{2}{*}{ Samples (n) } & \multicolumn{2}{|l|}{71} & \multicolumn{2}{|l|}{78} & \multicolumn{2}{|l|}{93} & \multicolumn{2}{|l|}{100} & \multicolumn{2}{|l|}{71} \\
\hline & $\begin{array}{l}\text { FP } \\
16\end{array}$ & $\begin{array}{l}\text { FN } \\
-\end{array}$ & $\begin{array}{l}\text { FP } \\
5\end{array}$ & $\begin{array}{l}\text { FN } \\
-\end{array}$ & $\begin{array}{l}\text { FP } \\
-\end{array}$ & $\begin{array}{l}\text { FN } \\
13\end{array}$ & $\begin{array}{l}\text { FP } \\
19\end{array}$ & $\begin{array}{l}\text { FN } \\
-\end{array}$ & $\begin{array}{l}\text { FP } \\
-\end{array}$ & $\begin{array}{l}\text { FN } \\
5\end{array}$ \\
\hline \multicolumn{11}{|l|}{ After second marker } \\
\hline $\begin{array}{l}\text { Creatine kinase } \\
\text { activity concentration }\end{array}$ & 6 & 14 & 1 & 7 & 3 & 11 & 2 & 12 & 2 & 5 \\
\hline $\begin{array}{l}\text { Creatine kinase-MB } \\
\text { mass concentration }\end{array}$ & 6 & 1 & 5 & 0 & 11 & 5 & 12 & 1 & 4 & 4 \\
\hline Troponin T & 7 & 4 & 4 & 2 & 20 & 3 & 12 & 4 & 12 & 1 \\
\hline Myoglobin & 4 & 15 & 2 & 16 & 2 & 6 & 4 & 19 & 2 & 3 \\
\hline
\end{tabular}

Abbreviations: URL, upper reference limit for creatine kinase activity concentration, $130 \mathrm{U} / \mathrm{h}$ for men and $90 \mathrm{U} / \mathrm{l}$ for women; FP and FN, false-positive and false-negative. $\mathrm{CK}=$ creatine kinase

onset of chest pain, three of these five patients could be detected because of an elevated creatine kinase activity concentration or creatine kinase slope. The second sample for these three patients was taken rather shortly after onset of chest pain (after 4.5, 6 and 7 hours). Moreover, one of these three patients had a new episode of chest pain four hours after the first one, while another was infused with 7 litres of fluid in the first five hours after admission. Therefore, reconsideration of these three patients revealed motives for continuation of sampling. Both myoglobin and troponin $\mathrm{T}$ were elevated in two (but not the same) of these three patients. One of the other two patients had acute myocardial infarction during coronary angiography, received thrombolytic therapy and was transferred to another hospital (both creatine kinaseMB mass concentration and troponin T were elevated), so further follow-up did not take place. The fifth patient, who was falsely considered to be without myocardial infarction based on this strategy $C$ including creatine kinase slope values, would be classified as having myocardial infarction by creatine kinase-slope when the result for creatine kinase activity concentration, measured for other reasons shortly before onset of chest pain, had been used for the evaluation (the admission sample was taken rather 
Tab. 5 Sensitivity (\%) and specificity (\%) for diagnostic strategy and normal electrocardiogram in various time-windows after onset A (see method section) in patients with,an ischaemic, inconclusive of symptoms.

\begin{tabular}{|c|c|c|c|c|c|c|c|}
\hline Marker & $\begin{array}{l}\text { Time- } \\
\text { window } \\
\text { (h)* }\end{array}$ & $\begin{array}{l}\text { Number of } \\
\text { patients } \\
\text { (patients with } \\
\text { acute myocardial } \\
\text { infarction) }\end{array}$ & $\begin{array}{l}\text { Creatine } \\
\text { kinase } \\
\text { activity } \\
\text { concentra- } \\
\text { tion }\end{array}$ & $\begin{array}{l}\text { Creatine } \\
\text { kinase-MB } \\
\text { activity } \\
\text { concentra- } \\
\text { tion }\end{array}$ & $\begin{array}{l}\text { Creatine } \\
\text { kinase-MB } \\
\text { mass } \\
\text { concentra- } \\
\text { tion }\end{array}$ & Troponin $\mathrm{T}$ & Myoglobin \\
\hline \multicolumn{6}{|c|}{ Electrocardiographic recording: ischaemic (sensitivity: 80\%) } & $\cdot 1$ & \\
\hline $\begin{array}{l}\text { Sensitivity } \\
\text { Specificity }\end{array}$ & $0-3$ & $28(25)$ & $\begin{array}{l}92 \\
67\end{array}$ & $\begin{array}{r}96 \\
100\end{array}$ & $\begin{array}{r}100 \\
67\end{array}$ & $\begin{array}{r}100 \\
67\end{array}$ & $\begin{array}{l}80 \\
67\end{array}$ \\
\hline $\begin{array}{l}\text { Sensitivity } \\
\text { Specificity }\end{array}$ & $3-6$ & $30(24)$ & $\begin{array}{l}92 \\
83\end{array}$ & $\begin{array}{r}92 \\
100\end{array}$ & $\begin{array}{l}96 \\
67\end{array}$ & $\begin{array}{l}96 \\
33\end{array}$ & $\begin{array}{l}79 \\
83\end{array}$ \\
\hline $\begin{array}{l}\text { Sensitivity } \\
\text { Specificity }\end{array}$ & $6-12$ & $19(13)$ & $\begin{array}{l}92 \\
33\end{array}$ & $\begin{array}{l}92 \\
50\end{array}$ & $\begin{array}{r}100 \\
17\end{array}$ & $\begin{array}{r}100 \\
0\end{array}$ & $\begin{array}{l}77 \\
67\end{array}$ \\
\hline $\begin{array}{l}\text { Sensitivity } \\
\text { Specificity }\end{array}$ & $0-12$ & $77(62)$ & $\begin{array}{l}92 \\
60\end{array}$ & $\begin{array}{l}94 \\
80\end{array}$ & $\begin{array}{l}98 \\
47\end{array}$ & $\begin{array}{l}98 \\
27\end{array}$ & $\begin{array}{l}79 \\
73\end{array}$ \\
\hline \multicolumn{8}{|c|}{ Electrocardiographic recording: inconclusive } \\
\hline $\begin{array}{l}\text { Sensitivity } \\
\text { Specificity }\end{array}$ & $0-3$ & $34(22)$ & $\begin{array}{l}95 \\
83\end{array}$ & $\begin{array}{l}82 \\
83\end{array}$ & $\begin{array}{l}95 \\
75\end{array}$ & $\begin{array}{l}86 \\
50\end{array}$ & $\begin{array}{l}91 \\
92\end{array}$ \\
\hline $\begin{array}{l}\text { Sensitivity } \\
\text { Specificity }\end{array}$ & $3-6$ & $18(15)$ & $\begin{array}{r}87 \\
100\end{array}$ & $\begin{array}{r}80 \\
100\end{array}$ & $\begin{array}{l}93 \\
67\end{array}$ & $\begin{array}{l}93 \\
67\end{array}$ & $\begin{array}{r}80 \\
100\end{array}$ \\
\hline $\begin{array}{l}\text { Sensitivity } \\
\text { Specificity }\end{array}$ & $6-12$ & $27(17)$ & $\begin{array}{l}88 \\
90\end{array}$ & $\begin{array}{r}82 \\
100\end{array}$ & $\begin{array}{r}100 \\
80\end{array}$ & $\begin{array}{r}100 \\
60\end{array}$ & $\begin{array}{l}76 \\
90\end{array}$ \\
\hline $\begin{array}{l}\text { Sensitivity } \\
\text { Specificity }\end{array}$ & $0-12$ & $79(54)$ & $\begin{array}{l}91 \\
84\end{array}$ & $\begin{array}{l}81 \\
92\end{array}$ & $\begin{array}{l}96 \\
76\end{array}$ & $\begin{array}{l}93 \\
56\end{array}$ & $\begin{array}{l}83 \\
92\end{array}$ \\
\hline \multicolumn{8}{|c|}{ Electrocardiographic recording: normal (specificity: 71\%) } \\
\hline $\begin{array}{l}\text { Sensitivity } \\
\text { Specificity }\end{array}$ & $0-3$ & $31(8)$ & $\begin{array}{l}75 \\
83\end{array}$ & $\begin{array}{l}75 \\
70\end{array}$ & $\begin{array}{r}100 \\
74\end{array}$ & $\begin{array}{r}100 \\
65\end{array}$ & $\begin{array}{l}75 \\
91\end{array}$ \\
\hline $\begin{array}{l}\text { Sensitivity } \\
\text { Specificity }\end{array}$ & $3-6$ & $22(6)$ & $\begin{array}{l}83 \\
81\end{array}$ & $\begin{array}{l}83 \\
88\end{array}$ & $\begin{array}{r}100 \\
81\end{array}$ & $\begin{array}{r}100 \\
81\end{array}$ & $\begin{array}{l}67 \\
88\end{array}$ \\
\hline $\begin{array}{l}\text { Sensitivity } \\
\text { Specificity }\end{array}$ & $6-12$ & $33(11)$ & $\begin{array}{l}91 \\
86\end{array}$ & $\begin{array}{l}91 \\
82\end{array}$ & $\begin{array}{r}100 \\
86\end{array}$ & $\begin{array}{l}91 \\
73\end{array}$ & $\begin{array}{l}73 \\
86\end{array}$ \\
\hline $\begin{array}{l}\text { Sensitivity } \\
\text { Specificity }\end{array}$ & $0-12$ & $86(25)$ & $\begin{array}{l}84 \\
84\end{array}$ & $\begin{array}{l}84 \\
79\end{array}$ & $\begin{array}{r}100 \\
80\end{array}$ & $\begin{array}{l}96 \\
72\end{array}$ & $\begin{array}{l}72 \\
89\end{array}$ \\
\hline
\end{tabular}

* Time-window: time period elapsed since onset of symptoms.

late). This patient also had elevated creatine kinase-MB mass concentration and troponin $T$.

\section{Combination of clinical and biochemical data}

The results of the electrocardiographic recordings at admission were classified as normal (specificity: 71\%), ischaemic (sensitivity: $80 \%$ ) or inconclusive. In each subgroup of patients, biochemical strategy $A$ and $C$ were evaluated again. Strategy B was not evaluated since it performed worse than strategy $C$. The results of this evaluation, shown in tables 5 and 6 , are related to the time-interval between onset of chest pain and admission.

\section{Discussion}

In patients with acute chest pain presenting shortly after onset ( $<12$ hours), accurate diagnosis is important to identify patients with myocardial infarction who might benefit from interventions aimed at limiting infarct size, avoiding premature hospital discharge of patients with myocardial infarction and assuring proper allocation of expensive coronary care beds. In patients with acute myocardial infarction, the presence of specific STchanges in the admission electrocardiogram usually has such a high positive predictive value $(1,36)$ that little further information is needed when this electrocardiographic finding is present in conjunction with appropriate symptoms. Unfortunately, a large proportion (this study: 57\%) of patients with acute myocardial infarction will have other findings on the admission electrocardiogram $(1,18,37)$ and many patients presenting with suggestive symptoms without characteristic findings on the admission electrocardiogram will have unstable angina or non-cardiac diagnoses. In these patients, biochemical markers of myocardial cell damage measured sequentially are the main tool in retrospectively establishing the definitive diagnosis. Objective biochemical data at admission usually are not available to be a part of the 
Tab. 6 Sensitivity (\%) and specificity (\%) for diagnostic strategy $\mathrm{C}$ (see method section) in patients with an ischaemic, inconclusive

\begin{tabular}{|c|c|c|c|c|c|c|}
\hline & \multirow{2}{*}{$\begin{array}{l}\text { Time-window } \\
\text { (h)* }\end{array}$} & \multirow{2}{*}{$\begin{array}{l}\text { Creatine kinase } \\
\text { slope }\end{array}$} & \multicolumn{4}{|l|}{ Second marker } \\
\hline & & & $\begin{array}{l}\text { Creatine } \\
\text { kinase-MB } \\
\text { activity } \\
\text { concentration }\end{array}$ & $\begin{array}{l}\text { Creatine } \\
\text { kinase-MB } \\
\text { mass } \\
\text { concentration }\end{array}$ & Troponin $\mathrm{T}$ & Myoglobin \\
\hline \multicolumn{7}{|c|}{ Electrocardiographic recording: ischaemic } \\
\hline $\begin{array}{l}\text { Sensitivity } \\
\text { Specificity }\end{array}$ & $0-3$ & $\begin{array}{r}100 \\
33\end{array}$ & $\begin{array}{r}96 \\
100\end{array}$ & $\begin{array}{r}100 \\
67\end{array}$ & $\begin{array}{l}100 \\
100\end{array}$ & $\begin{array}{l}80 \\
67\end{array}$ \\
\hline $\begin{array}{l}\text { Sensitivity } \\
\text { Specificity }\end{array}$ & $3-6$ & $\begin{array}{l}96 \\
67\end{array}$ & $\begin{array}{r}92 \\
100\end{array}$ & $\begin{array}{l}96 \\
67\end{array}$ & $\begin{array}{l}92 \\
67\end{array}$ & $\begin{array}{r}75 \\
100\end{array}$ \\
\hline $\begin{array}{l}\text { Sensitivity } \\
\text { Specificity }\end{array}$ & $6-12$ & $\begin{array}{l}92 \\
33\end{array}$ & $\begin{array}{l}92 \\
50\end{array}$ & $\begin{array}{l}92 \\
33\end{array}$ & $\begin{array}{l}92 \\
33\end{array}$ & $\begin{array}{l}77 \\
83\end{array}$ \\
\hline $\begin{array}{l}\text { Sensitivity } \\
\text { Specificity }\end{array}$ & $0-12$ & $\begin{array}{l}97 \\
47\end{array}$ & $\begin{array}{l}94 \\
80\end{array}$ & $\begin{array}{l}97 \\
53\end{array}$ & $\begin{array}{l}97 \\
67\end{array}$ & $\begin{array}{l}77 \\
87\end{array}$ \\
\hline \multicolumn{7}{|c|}{ Electrocardiographic recording: inconclusive } \\
\hline $\begin{array}{l}\text { Sensitivity } \\
\text { Specificity }\end{array}$ & $0-3$ & $\begin{array}{l}95 \\
75\end{array}$ & $\begin{array}{l}82 \\
92\end{array}$ & $\begin{array}{l}95 \\
75\end{array}$ & $\begin{array}{l}86 \\
75\end{array}$ & $\begin{array}{l}86 \\
92\end{array}$ \\
\hline $\begin{array}{l}\text { Sensitivity } \\
\text { Specificity }\end{array}$ & $3-6$ & $\begin{array}{r}93 \\
100\end{array}$ & $\begin{array}{r}80 \\
100\end{array}$ & $\begin{array}{r}87 \\
100\end{array}$ & $\begin{array}{r}87 \\
100\end{array}$ & $\begin{array}{r}87 \\
100\end{array}$ \\
\hline $\begin{array}{l}\text { Sensitivity } \\
\text { Specificity }\end{array}$ & $6-12$ & $\begin{array}{l}94 \\
80\end{array}$ & $\begin{array}{r}82 \\
100\end{array}$ & $\begin{array}{l}94 \\
90\end{array}$ & $\begin{array}{l}94 \\
80\end{array}$ & $\begin{array}{l}76 \\
90\end{array}$ \\
\hline $\begin{array}{l}\text { Sensitivity } \\
\text { Specificity }\end{array}$ & $0-12$ & $\begin{array}{l}94 \\
80\end{array}$ & $\begin{array}{l}81 \\
96\end{array}$ & $\begin{array}{l}93 \\
84\end{array}$ & $\begin{array}{l}89 \\
80\end{array}$ & $\begin{array}{l}83 \\
92\end{array}$ \\
\hline \multicolumn{7}{|c|}{ Electrocardiographic recording: normal } \\
\hline $\begin{array}{l}\text { Sensitivity } \\
\text { Specificity }\end{array}$ & $0-3$ & $\begin{array}{r}100 \\
70\end{array}$ & $\begin{array}{l}75 \\
87\end{array}$ & $\begin{array}{r}100 \\
83\end{array}$ & $\begin{array}{r}100 \\
83\end{array}$ & $\begin{array}{l}75 \\
96\end{array}$ \\
\hline $\begin{array}{l}\text { Sensitivity } \\
\text { Specificity }\end{array}$ & $3-6$ & $\begin{array}{r}100 \\
50\end{array}$ & $\begin{array}{l}83 \\
88\end{array}$ & $\begin{array}{r}100 \\
81\end{array}$ & $\begin{array}{r}100 \\
88\end{array}$ & $\begin{array}{l}67 \\
88\end{array}$ \\
\hline $\begin{array}{l}\text { Sensitivity } \\
\text { Specificity }\end{array}$ & $6-12$ & $\begin{array}{r}100 \\
73\end{array}$ & $\begin{array}{r}91 \\
100\end{array}$ & $\begin{array}{r}100 \\
86\end{array}$ & $\begin{array}{l}91 \\
86\end{array}$ & $\begin{array}{l}73 \\
95\end{array}$ \\
\hline $\begin{array}{l}\text { Sensitivity } \\
\text { Specificity }\end{array}$ & $0-12$ & $\begin{array}{r}100 \\
66\end{array}$ & $\begin{array}{l}84 \\
92\end{array}$ & $\begin{array}{r}100 \\
84\end{array}$ & $\begin{array}{l}96 \\
85\end{array}$ & $\begin{array}{l}72 \\
93\end{array}$ \\
\hline
\end{tabular}

* Time-window: time period elapsed since onset of symptoms.

decision making process, because the markers currently used, creatine kinase and creatine kinase-MB activity concentration, have a low diagnostic sensitivity at admission (this study: creatine kinase: $40 \%$; creatine kinase-MB: $34 \%$ ). The new markers (creatine kinase-MB mass concentration, troponin $\mathrm{T}$ and myoglobin) perform better in this respect and therefore are helpful in selecting therapeutic measures in patients with elevated results, notably when they are combined with the electrocardiographic findings $(26,33)$.

The objective of the present study was addressed to the aspect of excluding myocardial infarction in those patients who are not subjected to therapeutic measures aimed at obtaining early reperfusion. Efficient and early exclusion of acute myocardial infarction prevents inappropriate usage of expensive coronary beds by patients without myocardial infarction. The main problem in this

and normal electrocardiogram in various time-windows after the onset of symptoms (number of patients as in tab. 5).

Electrocardiographic recording: ischaemic

Specificity

100

92

100

92

50

94

80

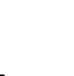


erful strategy than getting one early. Also measuring slope values did not seem to have any advantage. Therefore, if there is no clinical reason to measure such a marker at the time of admission, measurement of biochemical markers could be delayed to at least $10-12$ hours after onset of chest pain to confirm or exclude myocardial infarction. At least 10-12 hours should elapse since onset of chest pain before biochemical markers are able to exclude acute myocardial infarction efficiently (27).

Slope (timed sequential) measurements of creatine kinase have been proposed $(9,10,11)$ as a cost-effective approach to the diagnosis and exclusion of myocardial infarction within 12 hours after admission to hospital. This procedure, however, was questioned $(12,13)$. The cause for this debate originates from the fact that Collinson et al. $(9,10)$ evaluated a small number of patients, all having creatine kinase activity concentration at admission within the reference range, while the evaluation of Vijan et al. (12) also included a number of patients with creatine kinase activity concentration above the reference range. Creatine kinase slope values have been reported to be unreliable in detecting myocardial infarction in patients with initially elevated creatine kinase activity concentration (38), which may explain the diverging results obtained with the slope procedure. Another factor which may also influence the results of the slope procedure is thrombolytic treatment. The concomitant revascularization alters the release characteristics of cardiac markers, thereby enhancing the amount reaching the circulation rapidly (resulting in a negative slope value). Consequently, it is not to be expected that the frequency of falsenegatives will be increased by the use of diagnostic strategies. Myocardial infarction therefore might be excluded efficiently by creatine kinase, but confirmation of myocardial infarction still requires additional measurement of more cardiospecific markers.

Since measuring creatine kinase activity concentration is much cheaper than using the other markers and because it can be done easily on whole blood samples in the ward (39), we evaluated the efficiency of excluding myocardial infarction by one of the two creatine kinase based strategies. In spite of the results of the ROC-curve analysis which showed the slope procedure to be less efficient than the results of the second sample analysis, we included the slope procedure in biochemical diagnostic strategy C. In this strategy the slope calculation was applied only when the result for creatine kinase activity concentration in the admission sample was within the reference range. In the ROC-curve analysis creatine kinase slope values were determined for all samples whether the admission creatine kinase was normal or elevated. Comparison of biochemical strategy $B$, based on creatine kinase activity concentration measurements only, and biochemical strategy $C$, which included creatine kinase slope values, showed that the latter method excluded myocardial infarction better than the former. The better efficiency for strategy $\mathrm{C}$ is caused by patients with a final diagnosis of acute myocardial infarction, who showed only a small but significant increase for creatine kinase activity concentration within the reference range. This advantage for the creatine kinase slope procedure does not find expression in the ROC-curve comparison, because of the negative effect of patients with a negative creatine kinase slope value after an elevated creatine kinase activity concentration at admission. These patients are, however, selected by both our strategies on the basis of the elevated creatine kinase activity concentration at admission. Although the sensitivity for strategy $\mathrm{C}$, which includes creatine kinase slope values, did not reach $100 \%$, the procedure proved to be valuable. Five patients were missed by the slope procedure when the first two samples were considered. Four of them were detected by including a third sample. So the time between onset of chest pain and sampling should be taken into consideration. The fifth patient, although falsely classified as having no acute myocardial infarction, was included in the study despite special circumstances (myocardial infarction during coronary angiography with subsequent thrombolysis). Therefore, the biochemical diagnostic strategy $\mathrm{C}$ proved to be a very efficient biochemical procedure.

In clinical practice, the results of the electrocardiographic recordings are also available for the diagnostic process. Therefore, we evaluated the performance of strategy $A$ and $C$ in the three subgroups of patients based on the electrocardiographic findings at admission (tab. 5 and 6). An ischaemic pattern on the electrocardiogram is considered to constitute sufficient evidence for a myocardial event, the results of biochemical markers therefore are not to be part of the decision making process. Our data support such a view. The small number of patients without myocardial infarction in this subgroup cause the low and very variable specificity for the various markers. In patients with inconclusive electrocardiographic patterns, the measurement of creatine kinase mass concentration is the marker that performs best as a single analyte (sensitivity: 96\%). The creatine kinase slope procedure followed by measurement of creatine kinase mass concentration proves to be almost as good as creatine kinase mass concentration alone (sensitivity: 93\%) and this procedure can be performed at lower laboratory costs. In patients with a normal electrocardiogram, the mass 
concentration of creatine kinase- $\mathrm{MB}$ and the creatine kinase slope procedure (sensitivity for both: 100\%) exclude myocardial infarction when the results are within the reference range. Since the creatine kinase slope procedure is less expensive, it is preferred.

Applying a strategy with a sensitive and cheap marker for exclusion of myocardial infarction, i.e. creatine kinase, and a more cardiospecific and expensive marker for confirmation (troponin $\mathrm{T}$ or creatine kinase-MB mass concentration) was shown to be very efficient at limited laboratory costs, certainly when it is applied in a subgroup of patients with a rather low incidence of myocardial infarction. The rather high frequency of false-positives (low diagnostic specificity) using both strategies based on creatine kinase activity concentration can be reduced by assaying a second more cardiospecific marker for myocardial cell damage. This reduction of false-positives is accompanied by an additional increase of false-negatives (lowering the sensitivity). Actually, this procedure has been in use for years in the form of measurement of creatine kinase-MB activity concentration, but as table 4 shows, creatine kinase-MB mass concentration is a better marker with less additional false-negatives. Myoglobin (not a cardiospecific marker!) like creatine kinase-MB activity concentration also reduces the number of false-positives more than creatine kinaseMB mass concentration, but the frequency of additional false-negatives is considerably higher too. Both markers are therefore unsuitable for confirming myocardial infarction. Troponin $T$, another new cardiospecific marker, on the other hand performs more like creatine kinase-MB mass concentration. The frequency of false-positives for troponin $\mathrm{T}$ and creatine kinaseMB mass concentration is rather large, which is caused by the high frequency of patients with unstable angina pectoris with elevated results. Thus, the use of such a strategy for exclusion of myocardial infarction does not fully account for the significance of detecting minor myocardial damage in patients not yet fulfilling the criteria of the World Health Organization for diagnosis of acute myocardial infarction (frequency of false-positive results for troponin T: $28 \%$ and for creatine kinase-MB mass: $15 \%$ ). The occurrence of minor myocardial damage (micro-infarctions) often precedes fatal events. This was revealed by postmortem studies $(40,41)$. Therefore, patients with elevated concentrations of these new markers might have micro-infarctions and be at risk of developing major coronary artery disease (42-44). Since the "classic" cardiac enzymes constitute one of the cornerstones the diagnosis of acute myocardial infarction is based on in this study, tests with a higher sensitivity and probably also specificity for detection of myocardial cell necrosis (e. g. troponin T) are likely to perform worse if tested against these methods. For example, its specificity should be poorer, since more patients without myocardial infarction, but with minor myocardial damage will yield positive results with such a more sensitive assay and remain undetected by the older, less sensitive methods used as standard. Therefore, the way myocardial infarction was diagnosed biases against the more sensitive markers such as troponin $\mathrm{T}$ and creatine kinase-MB mass concentration. Thus calling patients without myocardial infarction and elevated concentrations of the more sensitive markers false-positive might not be justified. Using the results of the new sensitive markers, these patients will be discovered as a subgroup with an increased risk whose prognosis would probably improve with a more aggressive treatment (i.e. coronary angiography followed by subsequent revascularization).

Assays for biochemical markers must be rapid to be of value for clinical decision making. Today, a rapid assay for creatine kinase activity concentration is available (39), but for troponin $T$ and creatine kinase MB mass concentration such technology is not yet available for routine clinical practice. The low sensitivity of creatine kinase activity concentration at the time of admission prevents this biochemical marker from becoming a part of the decision process, which may lead to early interventions aimed at reducing infarct size. New markers like creatine kinase-MB mass concentration, myoglobin and troponin $\mathrm{T}$ are better suited for such purposes, especially when the results are combined with the outcome of the admission electrocardiogram (33). However, very rapid assays for these tests are not yet available for routine clinical practice and cardiologists have to rely on the outcome of the electrocardiogram. In patients with an ischaemic electrocardiogram the picture is rather clear, but in patients with a normal or inconclusive electrocardiogram it is not. For these patients, a diagnostic strategy based on creatine kinase activity concentration including slope values proved to be an efficient strategy for the exclusion of myocardial infarction, without the need of serial measurements of the expensive new tests. The need for calculating creatine kinase slope values was recently eliminated by the presentation of a simple nomogram (45). Such a nomogram should not be related to the time since admission as Johnson et al. proposed, but rather to the time since onset of chest pain. Since the cardiac markers (creatine kinase, creatine kinase-MB and troponins) start to rise 6-10 hours after onset of myocardial cell necrosis, the timeinterval since onset of symptoms needs to be taken into consideration for sampling. Sampling with shorter time-intervals than in the present study would probably 
allow earlier diagnosis and exclusion of myocardial infarction, but for exclusion of myocardial infarction the sampling period should be continued to at least 12 hours after onset of chest pain.

\section{Conclusion}

We have shown that

1. slope measurements of biochemical markers usually do not have any advantage over measuring the same marker at the time the second sample was gathered.

2. a creatine kinase based diagnostic strategy which includes creatine kinase slope measurements can efficiently exclude acute myocardial infarction in subgroups of patients when the time elapsed since onset of chest pain is taken into consideration (sampling until 12 hours after onset of symptoms is necessary).

\section{References}

1. Rude RE, Poole WK, Muller JE, Turi Z, Rutherford J, Parker C, et al. and the MILIS study group. Electrocardiographic and clinical criteria for recognition of acute myocardial infarction based on analysis of 3697 patients. Am J Cardiol 1983; 52:936-42.

2. Bar FW, Vermeer F, De Zwaan C, Ramentol M, Braat S, Simoons ML, et al. Value of admission electrocardiogram in predicting outcome of thrombolytic therapy. Am J Cardiol 1987; 59:6-13.

3. Adams J, Trent R, Rawles J, on behalf of the GREAT group. Earliest electrocardiographic evidence of myocardial infarction: implications for thrombolytic treatment. Br Med J 1993; 307:409-13.

4. Lee TH, Weisberg MC, Cook EF, Daley K, Brand DA, Goldman L. Evaluation of creatine kinase and creatine kinase-MB for diagnosing myocardial infarction. Arch Intern Med 1987; 147:115-21.

5. Moss DW, Henderson AR, Enzymes. In: Burtis CA, Ashwood ER, editors. Tietz Textbook of Clinical Chemistry. 2nd ed. Philadelphia; WB Saunders Company, 1994:735-896.

6. Griffiths PD. CK-MB a valuable test? [review]. Ann Clin Biochem 1986; 23:238-42.

7. Stein W, Bohner J, Bahlinger M. Analytical patterns and biochemical properties of macro creatine kinase type 2. Clin Chem 1985; 31:1952-8.

8. Rogalsky VY, Koven IH, Miller DR, Pollard A. Macro creatine kinase type 2 in human colonic tissues. Clin Biochem 1985; 18:338-41.

9. Collinson PO, Rosalki SB, Flather M, Wolman R, Evans $T$. Early diagnosis of myocardial infarction by timed sequential enzyme measurements. Ann Clin Biochem 1988; 25:376-82.

10. Collinson PO, Ramhamadany EM, Rosalki SB, Joffe J, Evans DH. Fink RS. et al. Diagnosis of acute myocardial infarction from sequential enzyme measurements obtained within 12 hours of admission to hospital. J Clin Pathol 1989; 42:1126-31.

11. Rutty G, Patel S, O'Gorman P. Application of the regression coefficient to timed serial creatine kinase measurements in the early diagnosis of myocardial infarction. Ann Clin Biochem 1989; 26:558-9.

12. Vijan SG, Ingle AR, Hill PG, Millar-Craig MW. Failure of creatine kinase slope values to reliably predict acute myocardial infarction. Ann Clin Biochem 1991; 28:103-4.
3. the frequency of false-positives obtained by a creatine kinase based strategy can be reduced by including a more cardiospecific and sensitive marker like creatine kinase-MB mass concentration or troponin $\mathrm{T}$.

4. applying the strategy with the creatine slope procedure for exclusion of myocardial infarction, and a more cardiospecific marker for confirmation (troponin $\mathrm{T}$ or creatine kinase-MB mass concentration) reduces laboratory costs, but does not fully account for detecting minor myocardial cell damage in patients not yet fulfilling the criteria of the World Health Organization for diagnosis of acute myocardial infarction.

\section{Acknowledgements}

The reagents and ES-33 analyzer for the immunological determination of troponin $T$ were granted by Boehringer Mannheim and the reagents for creatine kinase-MB mass concentration by Abbott.

13. Leung FY, Griffith AP, Jablonsky G, Henderson AR. Comparison of the diagnostic utility of timed serial (slope) creatine kinase measurements with conventional serum tests in the early diagnosis of myocardial infarction. Ann Clin Biochem 1991; 28:78-82.

14. Kagen L. Myoglobin: methods and diagnostic uses. Crit Rev Lab Sci 1978; 9:273-302.

15. Cairns J, Missirlis E, Walker W. Usefulness of serial determinations of myoglobin and creatine kinase in serum compared for assessment of acute myocardial infarction. Clin Chem 1983; 29:469-73.

16. McComb JM, McMaster EA, Adgey AAJ. Myoglobin in the very early phase of acute myocardial infarction. Ann Clin Biochem 1985; 22:152-5.

17. Roxin L, Cullhed I, Groth T, Hällgren T, Venge P. The value of serum myoglobin determinations in the early diagnosis of acute myocardial infarction. Acta Med Scand 1984; 215:417-25.

18. Ohman EM, Casey C, Bengtson JR, Pryor D, Tormey W, Horgan $\mathrm{JH}$. Early detection of acute myocardial infarction: additional diagnostic information from serum concentrations of myoglobin in patients without ST elevation. Br Heart J 1990; 63:335-8.

19. Delanghe JR, de Mol AM, de Buyzere ML, de Scheerder IK, Wieme RJ. Mass concentration and activity of creatine kinase isoenzyme MB compared in serum after acute myocardial infarction. Clin Chem 1990; 36:149-53.

20. Collinson PO, Rosalki SB, Kuwana T, Garratt HM, Ramhamadamy EM, Baird IM. Early diagnosis of acute myocardial infarction by $\mathrm{CK}-\mathrm{MB}$ mass measurements. Ann Clin Biochem 1992; 29:43-7.

21. Mair J, Artner-Dworzak E, Dienstl A, Lechleitner P, Morass $\mathrm{B}$, Smidt J, et al. Early detection of acute myocardial infarction by measurement of mass concentration of creatine kinase-MB. Am J Cardiol 1991; 68:1545-50.

22. Katus HA, Remppis A, Looser $S$, Hallermeier $K$, Scheffold $T$, Kübler W. Enzyme linked immuno assay of cardiac Troponin $T$ for the detection of acute myocardial infarction in patients. J Mol Cell Cardiol 1989; 21:1349-53.

23. Katus HA, Remppis A, Neumann FJ, Scheffold T, Diederich $\mathrm{KW}$, Vinar G, et al. Diagnostic efficiency of Troponin T measurements in acute myocardial infarction. Circulation 1991; $83: 902-12$ 
24. Katus HA, Looser S, Hallermayer K, Remppis A, Scheffold T, Borgya $A$, et al. Development and in vitro characterization of a new immunoassay of cardiac Troponin T. Clin Chem 1992; 38:386-93.

25. Gerhardt W, Katus HA, Ravkilde J, Hamm C, Jørgensen PJ, Peheim E, et al. S-Troponin $T$ in suspected ischemic myocardial injury compared with mass and catalytic concentrations of s-creatine kinase isoenzyme MB. Clin Chem 1991; 37:1405-11.

26. Bakker AJ, Gorgels JPMC, van Vlies B, Haagen FDM, Smits $R$. Serum troponin $T$ and CK-MB mass concentration are elevated before creatine kinase and its $\mathrm{MB}$-isoenzyme activity in acutc myocardial infarction. Eur J Clin Chem Clin Biochem 1993; 31:715-24.

27. Bakker AJ, Koelemay MJW, Gorgcls JPMC, van Vlies B, Smits R, Tijssen JGP, et al. Failure of new biochemical markers to exclude acute myocardial infarction at admission. Lancet 1993; 342:1220-2.

28. The Criteria Committee of the New York Heart Association. Nomenclature and criteria for diagnosis of diseases of the heart and great vessels. 8th ed. Boston: Little, Brown and Company, 1979.

29. Horder M, Elser RC, Gerhardt W, Mathieu M, Sampson EJ. Approved recommendation on IFCC methods for the mcasurement of catalytic concentrations of enzymes, part 7. IFCC method for creatine kinase. Eur J Clin Chem Clin Biochem 1991; 29:435- 56 .

30. Brandt DR, Gates RC, Eng KK, Forsythe CM, Korom GK, Nitro AS, ct al. Quantifying the $M B$ isoenzyme of creatine kinase with the Abbott "IMx" immunoassay analyzer. Clin Chem 1990; 36:375-8.

31. Bakker AJ, Boymans DAG, Dijkstra D, Gorgels JPMC, Lerk R. Rapid determination of serum myoglobin with a routine chemistry analyzer. Clin Chem 1993; 39:653-8.

32. Solberg HE. The theory of reference values part 5 . Statistical treatment of collected reference values. Determination of reference limits. J Clin Chem Clin Biochem 1983; 21:749-60.

33. Bakker AJ, Koelemay MJW, Gorgels JPMC, van Vlies B, Smits R, Tijssen JGP, et al. Troponin $T$ and myoglobin at admission: value for the early diagnosis of acute myocardial infarction. Eur Heart J 1994; 15:45-53.

34. Hanley JA, McNeil BJ. The meaning and use of the area under a Receiver Operating Characteristic (ROC) curve. Radiology $1982 ; 143: 29-36$.

35. Hanley JA, McNeil BJ. A method of comparing the areas under Receiver Operating Characteristic curves derived from the same cases. Radiology 1983; 148:839-43.
36. Yusuf S, Pearson M, Sterry H, Parish S, Ramsdale D, Rossi P. The entry ECG in the early diagnosis and prognostic stratification of patients with suspected acute myocardial infarction. Eur Heart J 1984; 5:690-6.

37. Pozen MW, D'Agostino RB, Selker HP, Sytkowski PA, Hood WB. A predictive instrument to improve coronary care unit admission practices in acute ischemic heart discase. $N$ Engl $\mathbf{J}$ Med 1984; 310:1273-8.

38. Dufour DR, LaGrenade A, Guerra J. Rapid serial enzyme measurements in evaluation of patients with suspected myocardial infarction. Am J Cardiol 1989; 63:652-5.

39. Braun HP, Deneke U, Rittersdorf W, Barl K. Construction and function of a new reflotron test for the determination of crcatine kinase [abstract]. Clin Chem 1990; 36:1129.

40. Davies MJ, Thomas AC, Knapman PA, Hangartner JR. Intramyocardial platelet aggregation in patients with unstable angina suffering sudden ischemic cardiac death. Circulation 1986; 73:418-27.

41. Falk E. Unstablc angina with fatal outcome: dynamic coronary thrombosis leading to infarction and/or sudden death: autopsy cvidence of recurrent mural thrombosis with peripheral embolization culminating in total vascular occlusion. Circulation 1985; 71:699-708.

42. Ravkilde J, Bo Hansen A, Hørder M, Jørgensen PJ, Thygesen $\mathrm{K}$. Risk stratification in suspected acute myocardial infarction based on a sensitive immunoassay for serum creatine kinase isoenzyme MB. Cardiology 1992; 80:143-51.

43. Markenvard J, Dellborg M, Jagenburg R, Swedberg K. The predictive value of CKMB mass concentration in unstable angina pectoris: preliminary report. J Intern Med 1992; 231:433-6.

44. Hamm CW, Ravkilde J, Gerhardt W, Jørgensen P, Peheim E, Ljungdahl $\mathrm{L}$, et al. The prognostic value of serum Troponin $\mathrm{T}$ in unstable angina. $\mathrm{N}$ Engl $\mathrm{J}$ Med 1992; 327:146-50.

45. Johnston JD, Collinson PO, Rosalki SB. MIDAS: Myocardial infarct diagnosis by assessment of slope. Ann Clin Biochem 1993; 30:407-9.

Dr. A. J. Bakker

Department of Clinical Chemistry

Klinisch Chemisch Laboratorium

P. O. Box 850

NL-8901 BR Leeuwarden

The Netherlands 


$$
\text { . }
$$

